\title{
Feeding strategies on certified organic dairy farms in Wisconsin and their effect on milk production and income over feed costs
}

\author{
C. A. Hardie, ${ }^{*}$ M. Wattiaux, ${ }^{*}$ M. Dutreuil, ${ }^{*}$ R. Gildersleeve, $†$ N. S. Keuler, $\ddagger$ and V. E. Cabrera ${ }^{* 1}$ \\ ${ }^{*}$ Department of Dairy Science, University of Wisconsin, Madison 53706 \\ †University of Wisconsin-Extension, Lancaster Agricultural Research Station, Lancaster 53813 \\ ‡Department of Statistics, University of Wisconsin, Madison 53706
}

\section{ABSTRACT}

The purposes of this study were (1) to analyze and categorize certified organic Wisconsin dairy farms based on general farm characteristics and feeding strategies during the course of 2010, and (2) to evaluate herd milk production and income over feed costs (IOFC). An onsite survey containing sections on farm demographics, feeding, grazing, and economics was conducted on 69 farms (12.6\% survey response rate). A nonhierarchical clustering method using 9 variables related to general farm characteristics, feed supplementation, and grazing was applied to partition the farms into clusters. A scree plot was used to determine the most appropriate number of clusters. Dry matter intake was approximated based on farmer-reported total amounts of feed consumed (feed offered less refusals). Milk production was evaluated using reported milk rolling herd averages (RHA). Income over feed costs was calculated as milk sales minus feed expenses. The farms in clusters 1 (n $=8)$ and $3(\mathrm{n}=32)$, the large and small high-input farms, respectively, included more feed ingredients in their lactating cow diets and relied more heavily on concentrates than farms in other clusters. Cows on these farms were predominantly Holstein. Clusters 1 and 3 had the highest RHA $(6,878$ and $7,457 \mathrm{~kg} /$ cow per year, respectively) and IOFC (\$10.17 and $\$ 8.59 /$ lactating cow per day, respectively). The farms in cluster $2(\mathrm{n}=5)$ were completely seasonal, extremely lowinput farms that relied much more heavily on pasture as a source of feed, with 4 out of the 5 farms having all of their operated land in pasture. Farms in cluster 2 relied on fewer feeds during both the grazing and nongrazing seasons compared with farms in the other clusters. These farms had the lowest RHA and IOFC at $3,632 \mathrm{~kg} /$ cow per year and $\$ 5.76 /$ lactating cow per day, respectively. Cluster $4(\mathrm{n}=24)$, the partly seasonal, moderate-input, pasture-based cluster, ranked third for RHA and IOFC $(5,417 \mathrm{~kg} /$ cow per year and

Received November 25, 2013.

Accepted March 26, 2014

${ }^{1}$ Corresponding author: vcabrera@wisc.edu
$\$ 5.92 /$ lactating cow per day, respectively). Breeds other than Holstein were used more prevalently on farms in clusters 2 and 4 . Results indicated extreme variation in animal breed, structure, and feeding strategies among Wisconsin organic dairy farms. Feeding strategies appeared to be major determinants of RHA and IOFC. These findings may serve current organic and transition farmers when considering feeding management changes needed to meet organic pasture rule requirements or dealing with dietary supplementation challenges.

Key words: organic dairy, feed supplementation, cluster analysis

\section{INTRODUCTION}

Feeding management on organic dairy farms has become an increasingly critical and complex task. In the United States during 2010, feed costs accounted for approximately $50 \%$ of total costs for producing milk (USDA-NASS, 2012). Furthermore, on June 17, 2010, the USDA National Organic Program finalized a pasture rule for organic ruminants (USDA-AMS, 2010). Organic dairy cattle of at least 6 mo of age must receive $30 \%$ or more of their DMI from pasture during the yearly grazing season, which must be at least $120 \mathrm{~d}$ long. Compliance with the pasture rule can create challenges for organic famers when balancing dairy rations. Harsh winters, limited land bases, drought, and many other factors prevent complete reliance on pasture for Wisconsin dairy cattle, requiring farmers to find additional feed sources for all or part of the year. Rising grain prices, limited and expensive harvested forages due to recent droughts (USDA-ERS, 2013), and the requirement that $100 \%$ certified organic feed must be fed to livestock have put extreme constraints on nonpasture feeding on certified organic dairy farms (USDA-AMS, 2013). Organic farming in the United States is further defined by its promotion of cultural and biological practices such as biodiversity, cycling of resources, and prohibition of use of synthetic fertilizers, herbicides, pesticides, antimicrobials, reproductive drugs, and genetically modified organisms (USDA-AMS, 2013). 
Wisconsin's prominent role in the nation's organic dairy industry makes it an important and necessary place to study this growing dairy sector. With $22 \%$ of the nation's total, Wisconsin ranks first in the United States for the total number of certified organic dairy farms (USDA-NASS, 2012). Conclusions drawn about Wisconsin's organic dairy farms could apply to similar farms in the northeastern United States because Wisconsin's organic farms are similar in size and structure to those located in the Northeast (McBride and Greene, 2009).

Although research on certified organic dairy farming in the United States is increasing, especially with comparisons to conventional farming (Zwald et al., 2004; Sato et al., 2005; Pol and Ruegg, 2007; Stiglbauer et al., 2013), few sources have focused on certified organic dairy farming alone. Furthermore, limited studies have focused on the relationship between feeding management, production performance, and profitability (McBride and Greene 2009; Hoshide et al., 2011; Marston et al., 2011). Thus, the purposes of this study were (1) to analyze and categorize certified organic Wisconsin dairy farms based on general farm characteristics and feeding strategies during the 2010 production year, and (2) to evaluate herd milk production and income over feed costs (IOFC).

\section{MATERIALS AND METHODS}

\section{Sampling}

To establish the sampling frame, 2 separate directories, the 2009 Wisconsin Active Dairy Producers list and the Wisconsin Certified Organic Producers list, were obtained from Wisconsin's Department of Agriculture, Trade and Consumer Protection (WDATCP, 2010). The first directory included all Wisconsin farms that sold milk in 2009. The second directory was a list of all Wisconsin farms that were certified organic in 2010, which included dairy, meat, and vegetable farms. The 2 lists were compared to create a list of Wisconsin organic dairy producers; names that appeared in both directories were assumed to be certified organic dairy producers in Wisconsin $(\mathrm{n}=554)$. All farmers on the resulting list were invited to participate in the study through a direct mailing that included an introductory letter, project summary, description of the project team members, and a prestamped postcard to be returned to the project team indicating level of interest in project participation. Farmers were also informed of a $\$ 100$ honorarium to be paid upon completion of the survey. Producers willing to participate were contacted by phone or mail to schedule an on-farm, face-to-face visit for survey administration. Farms $(\mathrm{n}=70)$ were surveyed between January 2011 and January 2012 regarding the 2010 production year.

\section{Survey Protocol}

The survey instrument (available at http:// DairyMGT.info/Survey.pdf) was 45 pages long and contained 98 questions and 46 tables to be completed within 9 general sections. The instrument was tested on 3 pilot farms before its use for research data collection. The instrument, consent form, and study protocol were approved by the University of Wisconsin-Madison Institutional Review Board (SE-2009-0401). Selected data from 7 sections of the survey were used in this study. The first portion of the survey focused on farm demographics - land operated and characteristics of the dairy herd. Additionally, the amount of milk sold, component figures, and milk price were obtained from milk check stubs for each month of 2010 . The middle sections of the survey focused on feed ingredient supplementation and grazing management practices. Farmers were asked to divide their herds into specific cow feeding groups (if applicable) and assess feed ingredient types and amounts consumed for all groups on a month-bymonth basis. The final portion of the survey assessed cropping strategies, homegrown feed costs, and other economic variables.

\section{Calculations}

Lactating cow DM consumption ( $\mathrm{kg} /$ cow per day) year round was approximated based on farmer-reported total amounts of feed consumed (feed offered less refusals) during the nongrazing-season months. Farmers who fed TMR or partial TMR obtained these values from feed sheets. Farmers who fed ingredients separately commonly obtained forage weights from harvest equipment and grain weights from feed mill slips. The difference between the approximated total daily DM consumed and the amount of feed supplements (all nonpasture feed) consumed during the grazing season was assumed to be DM consumed from pasture (pasture DM consumed $=$ total approximated DM consumed DM consumed from feed supplements during the grazing season), as outlined in Gehman et al. (2006) and Rego et al. (2008).

In this study, income referred specifically to revenue generated from milk sales. Feed costs were for lactating cows only and included expenses related to purchased feeds, homegrown feeds, and a calculated grazing cost. Cost estimates of the latter 2 items included seed, fertilizer, weed and pest control, and irrigation costs. Custom harvesting and labor, storage, and transportation costs were also included in feed costs for farms 
that had these costs. Depreciation for machines owned by the farmer, fuel, and unpaid labor were not included in the calculations. Thus, IOFC was calculated for each month as follows: IOFC (\$/lactating cow per day) = [monthly income from milk sales - (monthly expenses for grazing and feed supplements)]/(average number of lactating cows per day by month). Milk production was quantified by milk rolling herd average (RHA), which was available for all farms either through DHI records or as reported by the farmers based on bulk tank values. Milk RHA included milk sold and milk not sold and thus accounted for the substantial amounts of milk that may be used for calves on organic dairy farms because of unavailability of certified organic milk replacers.

\section{Cluster Analysis}

Farms were clustered based on 3 main areas: general characteristics and management, nonpasture feeding practices, and grazing practices. Within these areas, 3 quantitative variables were considered (Table 1). Variable selection was based on clustering goals and recommendations outlined in Weigel and Rekaya (2000) and Mooi and Sarstedt (2011). The 3 general farm variables used were cows per herd (= mean number of cows in the herd, lactating and dry combined), percentage Holstein
(= percentage of cows within the herd that were Holstein), and milking frequency (= weighted mean number of milkings per day, as a proxy to capture seasonal production). The 3 nonpasture feeding variables used were cow feeding groups (= total number of lactating and dry cow feeding groups on the farm), feed supplements (= total number of purchased and nonpasture homegrown feeds incorporated into the lactating cows' diet), and concentrates fed (= mean amount of concentrates fed to lactating cows; $\mathrm{kg}$ of $\mathrm{DM} / \mathrm{cow}$ per day). The 3 grazing variables used to judge farmers' incorporation of pasture into lactating cow feeding programs were land used as pasture (= percentage of each farm's operated land assigned to dairying primarily used as pasture), occupancy period (= number of days lactating cows remained in a paddock before being assigned to a new paddock), and grazing season length (= the 2010 length of grazing season for each farm).

A preliminary analysis identified one farm that had an incomplete data set and outlying values in 3 of the 9 clustering variables. Data from this farm were excluded from further analysis. Data were standardized by subtracting the means from each data point and dividing the differences by the standard deviations. A nonhierarchical (k-means) partitioning method was used to cluster the farms, as this method is minimally affected by outliers (Mooi and Sarstedt, 2011). Based on a scree

Table 1. Cluster and total sample medians (interquartile ranges; IQR) for the clustering and evaluated variables of Wisconsin certified organic dairy farms

\begin{tabular}{|c|c|c|c|c|c|c|c|c|c|c|}
\hline \multirow[b]{2}{*}{ Variable } & \multicolumn{2}{|c|}{$\begin{array}{c}\text { Cluster } 1 \\
(\mathrm{n}=8)\end{array}$} & \multicolumn{2}{|c|}{$\begin{array}{c}\text { Cluster } 2 \\
(\mathrm{n}=5)\end{array}$} & \multicolumn{2}{|c|}{$\begin{array}{l}\text { Cluster } 3 \\
(\mathrm{n}=32)\end{array}$} & \multicolumn{2}{|c|}{$\begin{array}{l}\text { Cluster } 4 \\
(\mathrm{n}=24)\end{array}$} & \multicolumn{2}{|c|}{$\begin{array}{l}\text { All farms } \\
(\mathrm{n}=69)\end{array}$} \\
\hline & Median & (IQR) & Median & (IQR) & Median & (IQR) & Median & (IQR) & Median & (IQR) \\
\hline \multicolumn{11}{|l|}{ Clustering } \\
\hline Cows per herd & $129^{\mathrm{a}}$ & (56) & $50^{\mathrm{b}}$ & $(35)$ & $41^{\mathrm{b}}$ & (14) & $43^{\mathrm{b}}$ & (51) & 45 & (41) \\
\hline Percentage Holstein $^{1}$ & $90^{\mathrm{a}}$ & (14) & $0.0^{\mathrm{b}}$ & $(0.0)$ & $89^{\mathrm{a}}$ & $(25)$ & $6.0^{\mathrm{b}}$ & $(22)$ & 71 & (89) \\
\hline Milking frequency ${ }^{2}$ & $2.0^{\mathrm{a}}$ & $(0.0)$ & $1.5^{\mathrm{b}}$ & $(0.43)$ & $2.0^{\mathrm{a}}$ & $(0.0)$ & $2.0^{\mathrm{a}}$ & $(0.0)$ & 2.0 & $(0.0)$ \\
\hline Concentrates fed ${ }^{5}$ & $5.7^{\mathrm{a}}$ & $(2.8)$ & $2.7^{\mathrm{ab}}$ & $(2.7)$ & $4.2^{\mathrm{a}}$ & $(1.4)$ & $1.9^{\mathrm{b}}$ & $(2.6)$ & 3.6 & $(2.6)$ \\
\hline Land used as pasture (\%) & $22^{\mathrm{c}}$ & $(20)$ & $100^{\mathrm{a}}$ & $(0.0)$ & $31^{\mathrm{c}}$ & $(14)$ & $49^{\mathrm{b}}$ & $(28)$ & 36 & $(24)$ \\
\hline Occupancy period $^{6}(\mathrm{~d})$ & $1.25^{\mathrm{a}}$ & $(1.25)$ & $0.50^{\mathrm{b}}$ & $(0.50)$ & $2.00^{\mathrm{a}}$ & $(3.25)$ & $0.50^{\mathrm{b}}$ & $(0.50)$ & 1.00 & $(2.00)$ \\
\hline Grazing season length (d) & $203^{\mathrm{a}}$ & $(21)$ & $216^{\mathrm{a}}$ & $(24)$ & $176^{\mathrm{b}}$ & $(36)$ & $199^{\mathrm{b}}$ & $(25)$ & 189 & $(39)$ \\
\hline \multicolumn{11}{|l|}{ Evaluated } \\
\hline $\mathrm{RHA}^{7}(\mathrm{~kg} /$ cow per year $)$ & $6,878^{\mathrm{a}}$ & $(1,038)$ & $3,632^{\mathrm{c}}$ & $(783)$ & $7,457^{\mathrm{a}}$ & $(1,754)$ & $5,417^{\mathrm{b}}$ & $(1,760)$ & 6,583 & $(2,520)$ \\
\hline $\operatorname{IOFC}^{8}(\$ /$ cow per $d)$ & $10.17^{\mathrm{a}}$ & $(2.99)$ & $5.76^{\mathrm{ab}}$ & $(1.62)$ & $8.59^{\mathrm{a}}$ & $(4.68)$ & $5.92^{\mathrm{b}}$ & $(2.47)$ & 7.73 & $(4.01)$ \\
\hline
\end{tabular}

${ }^{\mathrm{a}-\mathrm{c}}$ Medians within a row not sharing a common superscript are statistically different based on Wilcoxon test with Bonferroni correction $(P<$ $0.05)$.

${ }^{1}$ Percentage of cows within each farm that were Holstein.

${ }^{2}$ Weighted mean number of milkings per day.

${ }^{3}$ Total number of cow feeding groups on the farm.

${ }^{4}$ Total number of nonpasture feeds incorporated into the farm's lactating cow diet.

${ }^{5}$ Mean amount of concentrates fed to lactating cows (kg/cow per day).

${ }^{6}$ Number of days lactating cows remained in a paddock before being rotated to new pasture.

${ }^{7}$ Milk rolling herd average.

${ }^{8}$ Milk income over feed costs for lactating cows for January through November 2010; note: cluster $2(\mathrm{n}=4)$, cluster $3(\mathrm{n}=27)$, cluster $4(\mathrm{n}=20)$. 
plot (R Foundation for Statistical Computing, 2011), 4 clusters were identified as optimal to describe the 69 farms of this study. Because of the lack of normality in our data, clusters were differentiated further on selected variables using Kruskal-Wallis tests, which separated clusters based on medians. If the Kruskal-Wallis test was significant $(P<0.05)$, then pair-wise Wilcoxon rank-sum tests with Bonferroni corrections were used to determine which clusters differed significantly $(P<$ $0.05)$. All statistical analyses were performed using $R$ version 2.14.0 (R Foundation for Statistical Computing, 2011).

\section{RESULTS AND DISCUSSION}

The low survey response rate $(12.6 \%)$ can be attributed to multiple factors. The length of the survey likely deterred some farmers, and our population of interest was probably over-surveyed due to the surveys conducted by Paine and Gildersleeve (2011) and Stiglbauer et al. (2013) just before our survey. Additionally, nonresponders were not pursued with multiple mailings due to restrictions on our survey time window. Even though the survey response rate was low, we consider our sample to have been representative of Wisconsin certified organic dairy farms. As indicated below, median herds in this study were similar to previously reported studies of certified organic farms (Sato et al., 2005; McBride and Greene, 2009), and the geographic spread of the surveyed herds was comparable to that of the total sampling population.

\section{Cluster Descriptions}

The cluster analysis resulted in 4 distinct clusters (Table 1). Cluster 1 contained 8 farms that had the largest herd size (129 cows) and predominantly Holstein cows. Feeding strategies for lactating cows relied heavily on supplementation (types and amounts of nonpasture feed) and minimally on pasture, with peak pasture intake reaching only $40 \%$ of the lactating cows' diets. Cluster 2, the seasonal, low-input farms, contained 5 farms that utilized seasonal (spring) calving, heavily utilized breeds other than Holstein, and relied entirely on pasture and hay as the forages for their lactating cows during the grazing and nongrazing seasons, respectively. Cluster 3 consisted of 32 farms that were similar to farms in cluster 1 in feeding strategies and breed but were smaller in herd size (41 cows). Cluster 4 , the partly seasonal, moderate-input, pasture-based farms, contained 24 farms that had nongrazing season lactating cow feeding strategies similar to that of the farms in clusters 1 and 3 but heavier reliance on pasture as a forage source during the grazing season. Farms in cluster 4 primarily used breeds other than Holstein, a trait shared with farms in cluster 2 (Table 1).

\section{General Characteristics}

Cluster 1 had a significantly larger median herd size (129 cows per farm) compared with the other 3 clusters, which had medians between 41 and 50 cows per farm (Table 1). The median and distribution of herd sizes in this study were comparable to that observed in other Midwestern studies conducted with certified organic dairy farms. In the study by Sato et al. (2005) comparing production and management practices on Wisconsin conventional and organic dairy farms, the average organic herd size was 51 cows, similar to the overall farm median herd size of 45 cows observed in the current study (Table 1). In a study of organic dairy farming in the United States, McBride and Greene (2009) found a similar distribution of herd sizes, with $12.2 \%$ of the herds surveyed in the upper Midwest (Michigan, Minnesota, and Wisconsin) having at least 100 cows per farm; likewise, cluster 1 (11.6\% of the sampled farms) in the current study had a median herd size of 129 cows.

Approximately $90 \%$ of the cows in herds in clusters 1 and 3 were Holstein (Table 1). Farms in clusters 2 and 4, the pasture-based clusters, used other breeds much more heavily as purebreds and for crossbreeding. Only 5 of the farms in clusters 2 and 4 combined had predominantly $(\geq 50 \%)$ Holstein cows, 6 of the farms had predominantly Jersey cows, 2 of the farms had predominantly Brown Swiss cows, 2 of the farms had predominantly Milking Shorthorn cows, 11 of the farms had predominantly crossbred cows, and 3 of the farms used other breeds as purebreds. In total, 17 different breeds were represented in the crossbred cows of this study, including (in decreasing order of prevalence) Holstein, Jersey, Milking Shorthorn, Brown Swiss, and Normande. Others reported that breeds other than Holstein were frequently used by graziers because of their advantages in higher milk components, heat tolerance, utilization of grass, and fertility (Barrett et al., 2005; Paine and Gildersleeve, 2011; Smith et al., 2013). Crossbreeding in particular has been used for its advantage in reproductive efficiency, especially by farms utilizing seasonal calving (Auldist et al., 2007).

The majority of the farms in clusters 1 and 3 milked twice daily year round (Table 1) and exhibited fairly even distribution of calving throughout the year (data not shown). In contrast, cows that belonged to the farms in clusters 2 and 4 were managed much more seasonally. All of the farms in cluster 2 were completely seasonal - defined in this study as having at least 1 mo (February) in which the farms did not have any 
lactating cows - and most of the farms in cluster 4 implemented uni- or bi-seasonal calving (having predominantly 1 or 2 calving seasons, respectively) but usually did not have a month without lactating cows. Several seasonal farms implemented once-daily milking as cows neared the end of their lactations. None of the surveyed farms milked 3 times or more daily.

Fertilization varied tremendously between crops within farm and from farm to farm. The most common source of fertilizer was manure. Additionally, some farms used organically allowed N-P-K fertilizers, and others used soil amendments such as gypsum and other calcium-containing products, a fish blend, a boron product, or combinations of the above. All 7 of the farms that grew corn in cluster 1 applied a fertilizer to their corn; 6 of these farms applied manure to their corn and 4 applied an N-P-K fertilizer. The average amount spent by these cluster 1 farms on fertilizer was $\$ 118.26 /$ ha of corn. The majority of farms in clusters 3 and 4 fertilized their corn, too, as well as their newly seeded hayfields and pastures. The most common fertilizer for these farms' newly seeded hectares was manure, although $<33 \%$ of these farms applied soil amendments in addition. Very little mechanical fertilization occurred on farms in cluster 2 , with only 3 of the farms applying fertilizer on just a couple of hectares. The only reported weed control methods were mechanical (cultivation or flaming) and biological (crop rotation). None of the farmers reported pest control or chemical weed control.

\section{Feed Supplementation}

The number of cow feeding groups differed between clusters. All farms in cluster 1 separated dry cows from lactating cows, and 2 of the farms had multiple lactating cow feeding groups, resulting in a median number of cow feeding groups of 2 (Table 1 ). Seventy-five percent of the farms in cluster 3 separated dry cows from lactating cows. In contrast, only $58 \%$ of farms in cluster 4 had multiple cow feeding groups. Many of these farms in cluster 4 that penned lactating and dry cows together had smaller herd sizes and thus only a few dry cows at a time. Additionally, they milked their cows in tie stalls, allowing for supplementation of concentrates to only lactating cows during milking time. Having all cows in the same stage of lactation at the same time allowed for the farms in cluster 2 to manage all cows as a single group (Table 1).

The farms in clusters 1,3 , and 4 used significantly more feed ingredients in lactating cow rations than those in cluster 2 (Table 1). Farms in clusters 1 and 3 used more nonpasture feed as a proportion of the total diet during the grazing season compared with farms in clusters 2 and 4 (Figure 1). For cluster 1, the onset of the grazing season led to the largest reduction in the use of haylage (which included baleage; Figure 1a); cluster 3 had a more-even split reduction in hay and haylage upon the inclusion of pasture into the diet (Figure 1c). The average winter diet for farms in cluster 4 was similar to that in clusters 1 and 3 , but with more emphasis placed on hay and haylage and less on concentrates and corn silage (Figure 1d). However, much more dramatic decreases in hay and haylage as dietary ingredients occurred with the onset of grazing season on farms in cluster 4 compared with those in clusters 1 and 3 (Figure 1). The lactating cow diet for farms in cluster 2 was much simpler than in the other 3 clusters. All farms in cluster 2 relied entirely on pasture as the forage source for lactating cows during the peak grazing season (Figure 1b). The only forage supplemented during the nongrazing season on farms in cluster 2 was hay.

Although the median amount of concentrates fed $(\mathrm{kg} /$ cow per day) differed between clusters (Table 1), the amount fed within cluster remained consistent throughout the entire year (Figure 1). Lactating cows in cluster 1 received the largest amount of concentrates $(5.7 \mathrm{~kg} /$ cow per day), whereas those in cluster 4 received the smallest amount of concentrates $(1.9 \mathrm{~kg} /$ cow per day $)$. The low value for cluster 4 was due, in part, to 7 of the farms not feeding any concentrate ingredients (except for the corn grain in corn silage). The greatest change in concentrate supplementation throughout the year was observed in cluster 2, in which the proportion of concentrates in the diet peaked in April and then declined, reaching 0\% inclusion by February (Figure $1 \mathrm{~b})$. The use of vitamins and mineral premixes as well as kelp meal (Ascophyllum nodosum), which is used primarily as a mineral and vitamin source in organic dairy farms, remained fairly consistent throughout the year for all 4 clusters (Figure 1). Kelp was incorporated into lactating cow diets in approximately one-half of the farms in each cluster (Table 2).

The feeding of mixed feed (partial TMR in the grazing season and TMR in the nongrazing season) and use of a nutritionist varied among clusters. Cluster 1 incorporated these feeding strategies most frequently, with $75 \%$ of the farms feeding mixed feed and all 8 of the farms receiving advice from a nutritionist (Table 2). Cluster 2 used these strategies the least, with none of the farms feeding mixed feed and only 2 of the 5 farms using a nutritionist (Table 2).

Increasing the types and amount of feed ingredients fed to pasture-based cows is a strategy to improve milk production. The greater percentage of dietary DM fed as nonpasture feed ingredients in lactating cow diets of clusters 1 and 3 during the grazing season could be attributed, at least in part, to the Holstein breed found in the same clusters. Holstein cows have a higher milk 
Table 2. Grazing and feed supplementation characteristics of the 4 clusters and the total sample

\begin{tabular}{|c|c|c|c|c|c|}
\hline Item & Cluster 1 & Cluster 2 & Cluster 3 & Cluster 4 & All farms \\
\hline \multicolumn{6}{|l|}{ Grazing characteristics } \\
\hline Grazing season start date & Apr 19 & Apr 26 & May 1 & Apr 22 & Apr 26 \\
\hline Grazing season end date & Nov 7 & Nov 28 & Oct 21 & Nov 8 & Nov 1 \\
\hline Access to pasture $(\mathrm{h} / \mathrm{d})$ & 16.9 & 21.6 & 19.2 & 21.0 & 19.6 \\
\hline Used leader/follower ${ }^{1}$ ( $\%$ of farms) & 50.0 & 40.0 & 19.4 & 29.2 & 27.9 \\
\hline \multicolumn{6}{|l|}{ Feeding strategy characteristics } \\
\hline Used a nutritionist (\% of farms) & 100 & 40 & 81 & 50 & 70 \\
\hline Fed mixed feed ( $\%$ of farms) & 75 & 0 & 41 & 13 & 32 \\
\hline \multicolumn{6}{|l|}{ Feed ingredient use ( $\%$ of farms) } \\
\hline Concentrates & 100 & 80 & 97 & 71 & 87 \\
\hline Soybeans & 63 & 0 & 25 & 4 & 20 \\
\hline Corn silage & 88 & 0 & 44 & 38 & 49 \\
\hline Haylage & 100 & 0 & 22 & 79 & 77 \\
\hline Hay & 75 & 100 & 25 & 83 & 80 \\
\hline Kelp meal & 50 & 40 & 47 & 54 & 49 \\
\hline
\end{tabular}

${ }^{1}$ Leader/follower is a grazing management strategy in which a group of animals, commonly dry cows or heifers, immediately graze a pasture after removal of another group of animals, such as lactating cows.

production response to concentrate feeding compared with other breeds (White et al., 2002). Furthermore, in agreement with the current study's findings, Bargo et al. (2002) concluded that a feeding strategy based on pasture plus partial TMR (similar to the lactating cow diets of clusters 1 and 3) resulted in higher milk production than a feeding strategy based on pasture plus concentrates (similar to many of the lactating cow diets of clusters 2 and 4). Nevertheless, compared with no-grain pasture diets, Bargo et al. (2003) concluded that milk production increases linearly ( $1 \mathrm{~kg}$ of milk/ $\mathrm{kg}$ of concentrate) with the addition of up to $10 \mathrm{~kg}$ of concentrates/cow per day.

The larger number of feed ingredients in the diets containing corn silage for clusters 1,3 , and 4 was not surprising. Hoshide et al. (2011) argued that perennial, (a) Cluster 1

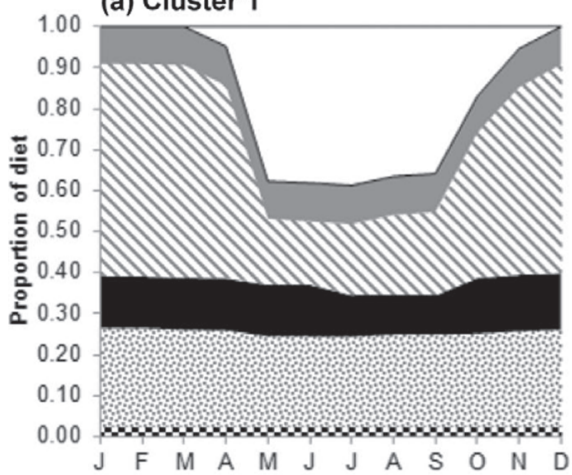

(c) Cluster 3

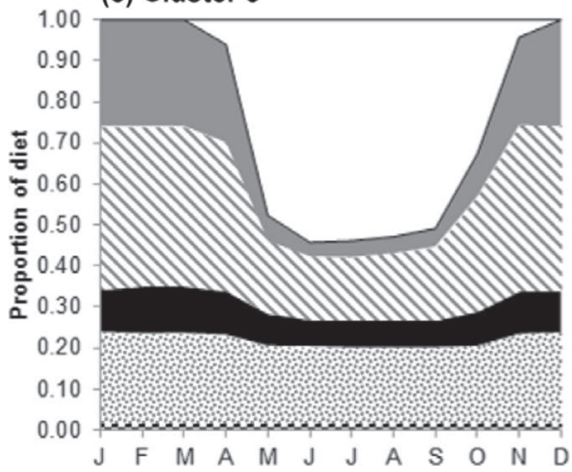

(b) Cluster 2

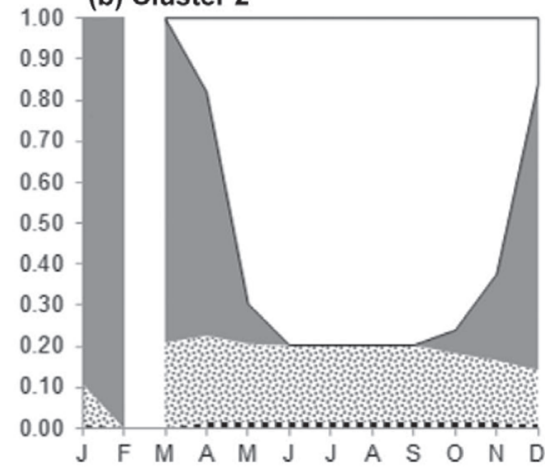

(d) Cluster 4

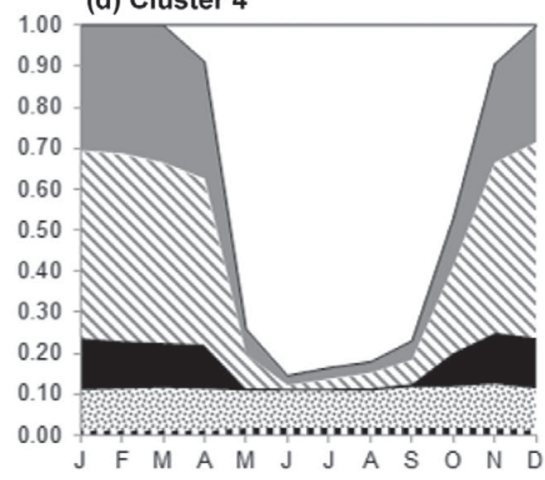

Figure 1. Proportion of feeds (on a DM basis) in the average lactating cow diet for each month of 2010 for each cluster. Note: in cluster 2 , the white bar in February indicates that there were no lactating cows during that time on any of that cluster's farms. 
sod-based diets (diets containing only grass/legume pasture, hay, and haylage) provided ample amounts of protein to lactating cows if the forages were harvested at appropriate stages of maturity. However, diets that incorporated several corn products in the form of grain and silage need to also include protein-rich ingredients to reach an adequate level of dietary $\mathrm{CP}$ concentration. This strategy was apparent in our study because $62.5 \%$ of the farms in cluster 1 used soybeans as a dietary ingredient, but no farms did so in cluster 2 (Table 2).

\section{Grazing}

Farms in clusters 2 and 4 relied much more heavily on pasture as a feed source for lactating cows than farms in clusters 1 and 3. The median percentages of land as pasture was greater for clusters 2 and 4 (100 and $49 \%$, respectively) than for clusters 1 and 3 (22 and $31 \%$, respectively; Table 1). Lactating cows in clusters 2 and 4 were assigned to a fresh paddock more frequently, having median paddock occupancy periods of $0.5 \mathrm{~d}$ ( 2 rotations/d) compared with paddock occupancy periods $>1 \mathrm{~d}$ for clusters 1 and 3 . Cows in cluster 2 had the most hours of access to pasture (21.6 h, Table 2) and the longest grazing season (216 d, Table 1) due to a grazing period that extended late into the fall by using hayfields and alternative forage crops (Table 2). The main forage species reported by farmers from all clusters included orchardgrass (Dactylis glomerata), Kentucky bluegrass (Poa pratensis), quackgrass (Elymus repens), timothy (Phleum pratense), red clover (Trifolium pratense), white clover (Trifolium repens), and alfalfa (Medicago sativa).

Farms in all 4 clusters met the USDA-AMS (2010) pasture rule requirements of $30 \% \mathrm{DMI}$ from pasture for at least $120 \mathrm{~d}$ (Figure 1). However, the incorporation of pasture by the surveyed farms had its advantages and disadvantages. Feed expenses during the grazing season months were among the lowest for all 4 clusters (Figure 2c), which is in agreement with the concept that dairy producers may turn to pasture-based feeding strategies in part because of reduced feed costs (Clark and Kanneganti, 1998). Increases in milk sold per cow were observed in all 4 clusters following the onset of the grazing season, which can be attributed to the nutritious and abundant pasture during the spring as well as cows reaching peak lactation for herds with seasonal calving (clusters 2 and 4). However, it is well documented that primary reliance on grazed forage for lactating cow diets may result in overall reduced milk production compared with cows fed a diet that contains some stored feed or all stored feed due to inadequate dietary energy supply (Leaver, 1985; Kolver and Muller, 1998; Bargo et al., 2003).
Rotating lactating cows more frequently to allow for more uniform pasture composition and consumption and to prevent cows from immediately grazing pasture regrowth (Undersander et al., 2002) was a strategy that pasture-based farms such as those in clusters 2 and 4 have implemented to improve production and management. Implementing a leader-follower system, whereby dry cows or heifers follow lactating cows, was another grazing strategy that some of the farmers used in all 4 clusters (Table 2). Mayne et al. (1988) observed that implementation of leader-follower grazing resulted in better utilization of available herbage and a $26 \%$ increase in milk production of high-producing cows.

\section{Milk Production, Composition, and IOFC}

Clusters 1 and 3 had the largest median RHA (6,878 and $7,457 \mathrm{~kg} /$ cow per year, respectively; Table 1$)$. Cluster 4 ranked third for RHA $(5,417 \mathrm{~kg} /$ cow per year) and cluster 2 had the lowest RHA $(3,632 \mathrm{~kg} /$ cow per year). For clusters 1, 3, and 4, milk fat and protein percentages remained fairly consistent throughout the year, although slight dips occurred during the summer (Figure 3). In the same clusters, noticeable peaks in SCC occurred during late summer. Summer decreases in milk fat and protein percentages and peaks in SCC have been observed nationally (USDA-ARS, 2013). In contrast, a unique set of patterns of changes in component concentrations and SCC could be observed for the milk of cows in cluster 2. For example, the sharp increase in milk component concentrations during the late fall and the extremely high values in January could be attributed to several factors, including breed, stage of lactation, number of milkings per day, and feeding strategies. A reduction in milk yield late in lactation or a decrease in the number of milkings per day leads to production of a more concentrated milk (Stelwagen et al., 2013). Furthermore, milk produced by cows not consuming pasture has a higher fat concentration than milk produced by cows on pasture (Bargo et al., 2003).

Farms in clusters 1 and 3 had the highest IOFC (\$10.17 and $\$ 8.59 /$ lactating cow per day, respectively; Table 1). Cluster 4 ranked third $\$ \$ 5.92 /$ lactating cow per day) and cluster 2 had the lowest IOFC (\$5.76/lactating cow per day). The Wilcoxon test with Bonferroni correction indicated that IOFC of farms in cluster 4 was significantly lower than that in all other clusters in spite of a higher numerical value compared with cluster 2. This situation arose most likely from the small number of farms in cluster 2 compared with the number in cluster 4 . The IOFC for all 4 clusters peaked in late spring during the months of May or June and then slowly declined as 2010 progressed (Figure 2d). Cluster 2 had particularly low IOFC for the first 4 mo of the 

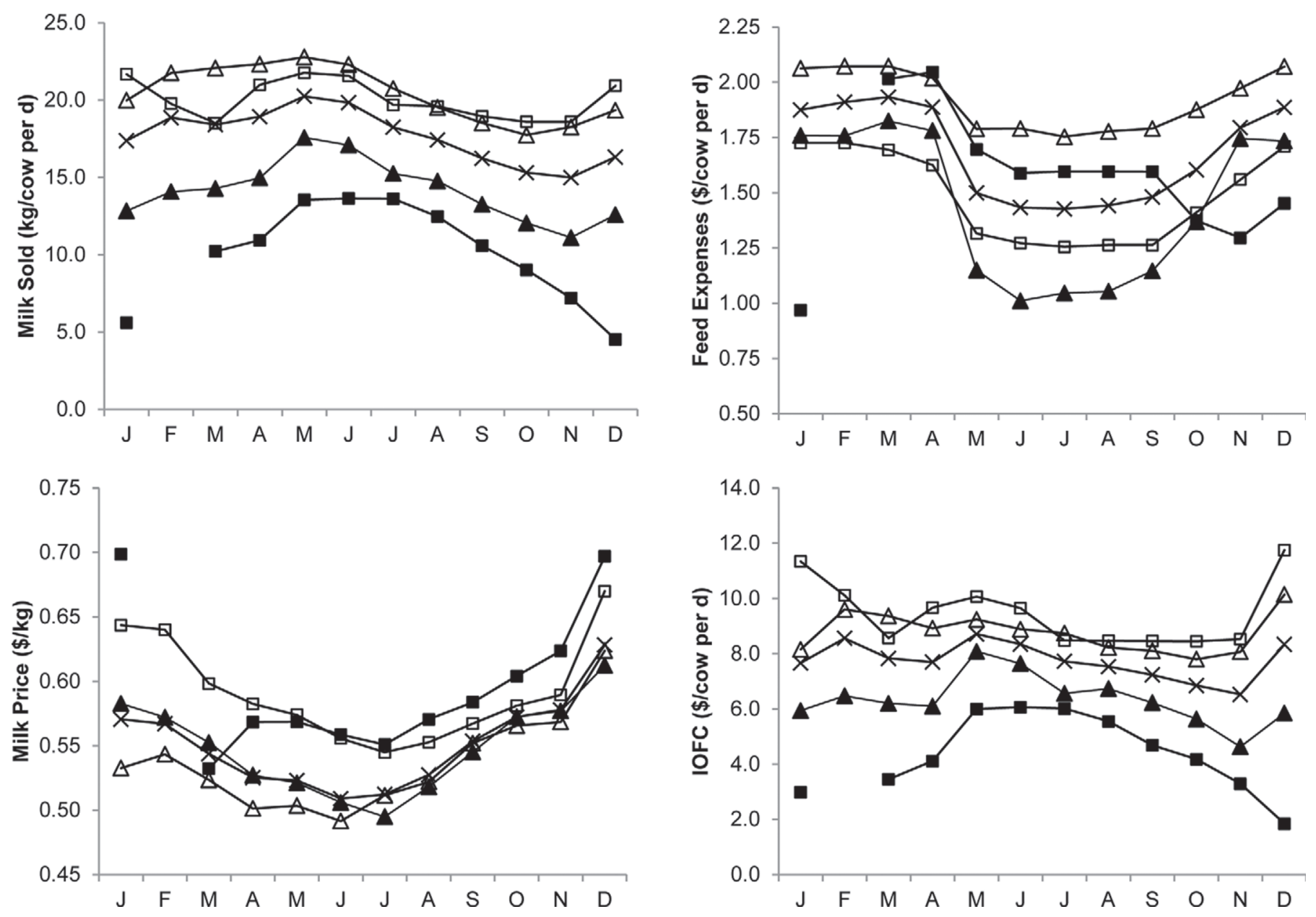

Figure 2. (a) Milk sold, (b) milk price, (c) feed expenses, and (d) milk income over feed costs (IOFC) by month of 2010 , for the 4 clusters. Note: only approximately one-half of the farms in each cluster had milk data (thus IOFC) available for December 2010. The absence of points in February for cluster 2 indicates that there were no lactating cows during that month on any of that cluster's farms. $\square=$ cluster $1, \boldsymbol{\square}=$ cluster $2, \Delta=$ cluster $3, \boldsymbol{\Delta}=$ cluster 4 , and $\times=$ all farms. Cluster averages (SD) for milk sold (kg/cow per day): cluster 1: 20.1 (1.27), cluster 2: 10.1 (3.25), cluster 3: $20.4(1.78)$, cluster 4: $14.2(1.94)$; milk price $(\$ / \mathrm{kg})$ : cluster 1: $0.59(0.040)$, cluster 2: 0.60 (0.056), cluster 3: 0.54 (0.037), cluster 4: 0.55 (0.036); feed expenses (\$/cow per day): cluster 1: $1.49(0.21)$, cluster 2: $1.57(0.31)$, cluster 3: 1.92 (0.14), cluster 4: 1.45 (0.35); IOFC (\$/cow per day): cluster 1: 9.46 (1.18), cluster 2: 4.38 (1.42), cluster 3: 8.77 (0.72), cluster 4: 6.34 (0.90).

year. The largest clusters, clusters 3 and 4 , had much more consistent IOFC throughout the year.

In this study, the higher RHA and IOFC for clusters 1 and 3 were likely due to breed and feeding strategies throughout the year. Using the integrated farm system model, Hoshide et al. (2011) also found that larger organic farms relying more heavily on nonpasture feed were $\$ 2.47 /$ cow per day more profitable than small organic farms relying on a perennial sod-based feeding system, even though breed and milk production $(6,531$ $\mathrm{kg}$ /cow per year) were kept constant across simulations.

The larger median herd size of cluster 1 could have contributed to higher IOFC compared with farms in the other clusters because of economies of scale. Even though farms in cluster 1 used the most feed ingredients, they had the least amount of feed expenses $(\$ /$ cow per day) for most months in 2010 (Figure 2c). This advantage was particularly noticeable when comparing clusters 1 and 3. Everything else being more or less equal, the ability to distribute capital investment in equipment and storage facilities for homegrown feeds across more animals was likely a contributing factor to the higher numerical IOFC of cluster 1 compared with cluster 3. This contention is supported by results of Hoshide et al. (2011), who found a positive association between net farm income per cow and herd size across an array of feed production systems.

The economic conditions of dairy farming in Wisconsin were not favorable during the timeframe of this survey. Milk prices received by some farmers were not true representations of organic premiums as several farmers reported having to sell milk to conventional processors 
(a) Cluster 1

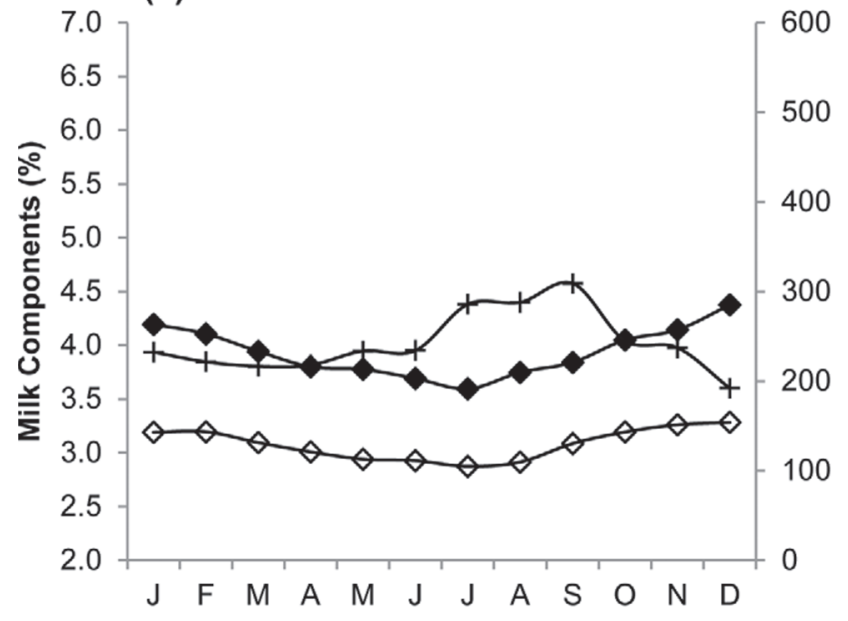

(b) Cluster 2

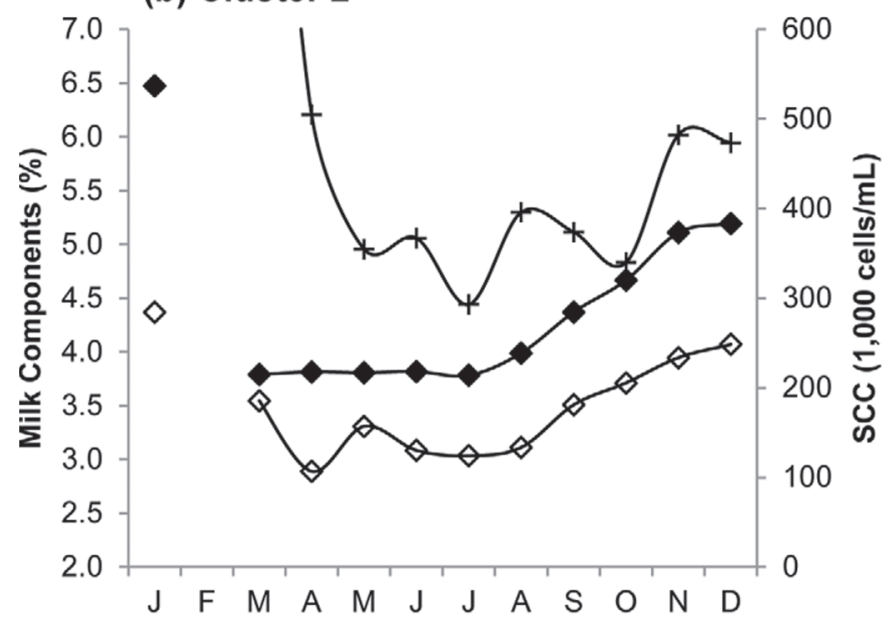

(c) Cluster 3

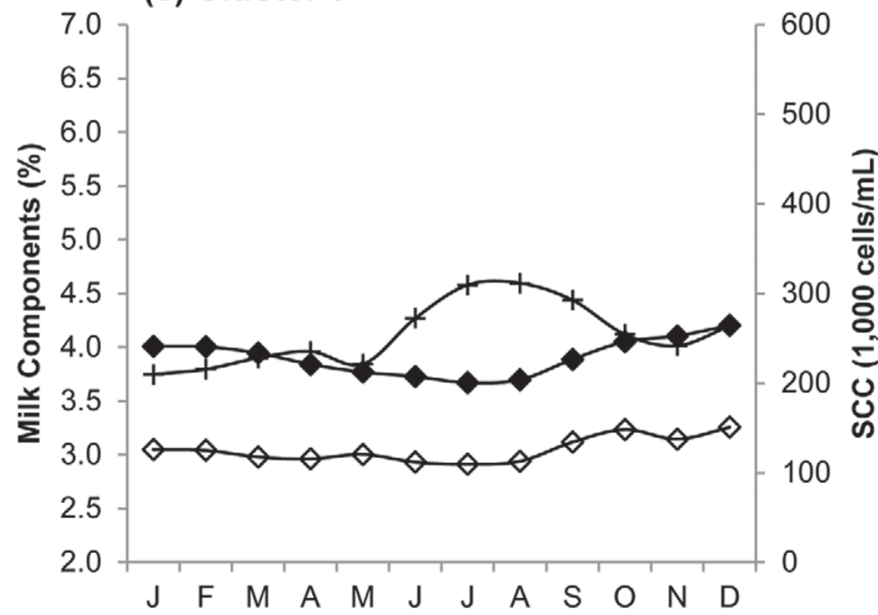

(d) Cluster 4

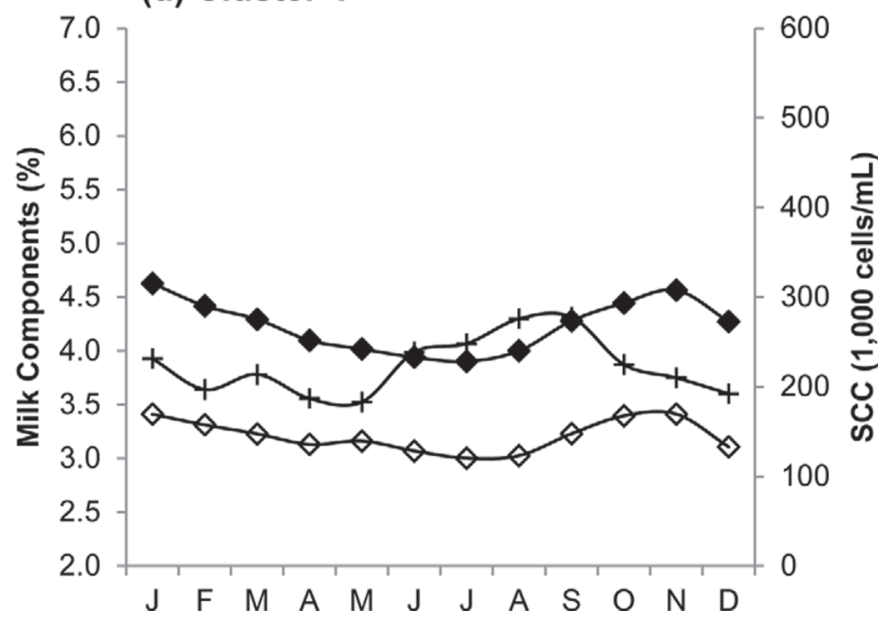

Figure 3. Milk component contents $(\%$ fat $=\diamond, \%$ protein $=\diamond)$ and SCC $(+)$ for each month of 2010 by cluster. Note: in cluster 2 , the missing values in February indicate that there were no lactating cows on any of that cluster's farms during that month, and the SCC values for January and March were $>600,000$ cells $/ \mathrm{mL}$. Average (SD) for \% fat, \% protein, and SCC (1,000 cells/mL), respectively, by cluster: cluster 1: $3.94(0.24), 3.08(0.14)$, and 243 (34.3); cluster 2: 4.44 (0.86), $3.51(0.48)$, and 487 (233); cluster 3: $3.91(0.17)$, 3.05 (0.12), and 255 (35.7); cluster 4: 4.24 (0.25), 3.21 (0.15), and 223 (32.4).

after losing their organic buyers or being placed in a probationary pool until the fall months after having found another organic buyer. During probation, these farms received an intermediate milk price between the conventional price and the common organic premium prices. Additionally, some organic farmers were placed on a quota system during the second half of 2009 and the first part of 2010, and those who exceeded the allotted quota received conventional prices for any milk sold above quota. The increase in IOFC toward the end of 2010 could be due to increased price premiums implemented by some co-ops during the winter as an incentive for farmers to increase milk production during winter shortages and reduce milk production during spring surpluses (Figure 2).
Differences in IOFC between farms within cluster were also explored and it was concluded that no one factor was the single determinant of IOFC. In most cases, the farms within each cluster that had the highest IOFC did not sell the most milk per cow, receive the best pay price, or incur the least expenses for feed; rather, they exhibited an ideal blend of multiple factors. In cluster 1 , the 2 farms with the largest IOFC ranked second and third out of the 8 farms for milk sold $(\mathrm{kg} /$ cow per day), ranked first and seventh for milk price $(\$ / \mathrm{kg})$, and had the lowest feed expenses $(\$ /$ cow per day). In cluster 3 , the 3 farms with the largest IOFC also sold the most milk per cow, received only a moderate milk price $(\$ 0.55 / \mathrm{kg})$, but varied widely in feed expenses $(\$ /$ cow per day) compared with their other 
cluster members. In cluster 4, 2 of the top 3 farms were in the top 3 for milk sold ( $\mathrm{kg} / \mathrm{cow}$ per day), and all 3 of the top 3 farms were in the top half for milk price received $(\$ / \mathrm{kg})$ but varied widely for feed expenses $(\$ /$ cow per day) compared with their cluster members.

\section{Milk Price Sensitivity Analysis}

Because milk prices were depressed during study year 2010, an unusual year, a sensitivity analysis for milk price was performed. Three different milk price scenarios were explored to determine their influence on median cluster IOFC. In the first scenario, all milk prices were increased by $20 \%$ to better represent organic premiums. The second scenario involved increasing the original milk prices by $40 \%$ to represent optimal milk premiums. In the third scenario, the average milk price received by the surveyed farms in $2010(\$ 0.5498 / \mathrm{kg})$ was entered for all farms. For all 3 scenarios, the ordering of the clusters based on median milk price remained the same as that presented in Table 1, with cluster 1 having the highest IOFC, followed by cluster 3 , then cluster 4 , and finally cluster 2 . With each 20 -percentage-point increase in milk price, the difference in IOFC between clusters 1 and 2 was expanded. Between the 3 scenarios, median IOFC ranged from $\$ 14.93$ for cluster 1 with the $40 \%$ increase in milk price to $\$ 4.28$ for cluster 2 with the average milk price of $\$ 0.5498 / \mathrm{kg}$.

\section{Determination of DMI from Pasture}

Determining the proportion of the diet during the grazing season that was from pasture was an essential, yet challenging, component of in this study. Several animal- and pasture-based techniques have been established for measuring total and pasture DMI for grazing cows (Bargo et al., 2003); however, because pasture material was not sampled, external and internal markers were not used, and fecal samples were not collected to estimate fecal output of DM and herbage DMI, determinations of total DMI and the proportion of pasture were limited to using farmer-reported data and prediction equations. In a review on methods and equations for estimating DMI in grazing cows, Bargo et al. (2003) concluded that NRC (2001) equation $1-2\left[\mathrm{DMI}=\left(0.372 \times \mathrm{FCM}+0.0968 \times \mathrm{BW}^{0.75}\right) \times\right.$ $\left.\left(1-\mathrm{e}^{[-0.192 \times(\mathrm{WOL}+3.67)]}\right)\right]$, where WOL $=$ week of lactation, was sufficient for calculating DMI for grazing cows. Furthermore, this equation had the advantage of requiring only animal factors compared with other proposed prediction equations that required herbage mass, pasture allowance, sward height, NDF in pasture, and percentage of legumes in pasture (Caird and Holmes,
1986; Vazquez and Smith, 2000). Thus, DMI using NRC (2001) equation 1-2 was calculated using a single, average $\mathrm{BW}$ per herd based on the average BW reported by the farmer for each breed on the farm, 4\% FCM calculated as milk sold plus milk not sold but used on farm, and assuming that average WOL was at least 20, resulting in a value of 1 for the exponential term. The DMI calculated using NRC (2001) was then compared with DMI obtained from farmer-reported information and the assumption that DMI in the grazing season was identical to DMI during the nongrazing season months of the year. Results of this comparison are presented in Figure 4. Although both methods are in general agreement, DMI from farmer-reported values were roughly 1 to $2 \mathrm{~kg} / \mathrm{d}$ higher than the NRC prediction for cows in clusters 1,3 , and 4 . Because of the built-in assumptions in each method, it is likely that the actual DMI for cows in clusters 1,3 , and 4 was intermediate to the curves presented in Figure 4. For example, DMI values obtained from farmer-reported information may have been over-estimated because they likely did not account for wasted feed or refusals. On the other hand, DMI values calculated from the NRC equation may have been under-estimated because the equation used did not account for the additional DMI that was required to provide cows with the energy to walk substantial distances during the grazing season. For cows in cluster 2 , the 2 methods were in almost perfect agreement, yet using the daily nongrazing (late-lactation) DMI to estimate grazing season (peak lactation) DMI for the spring-calving herds in this cluster likely caused an underestimation of DMI using the differential method. Thus, our analysis suggested that approximating total DMI based on farmer-reported feed ingredient types and amounts fed during the nongrazing season, assuming that total DM remain constant throughout the year, to calculate pasture DMI during the grazing season appears to be reliable and valid. Furthermore, this method proved useful in constructing diet composition.

\section{CONCLUSIONS}

Wisconsin's organic dairy farms differ significantly in size, feeding management, productivity, and IOFC. Despite the survey's low response rate, we conclude that farms having predominantly Holstein cows and relying on a greater variety of feed ingredients and greater amounts of nonpasture feeds had the highest IOFC and largest reported RHA compared with farms using predominantly non-Holstein breeds and relying more heavily on grass-based diets. However, caution should be used when interpreting the results due to the gross estimation of DMI. Research evaluating other 
(a) Cluster 1

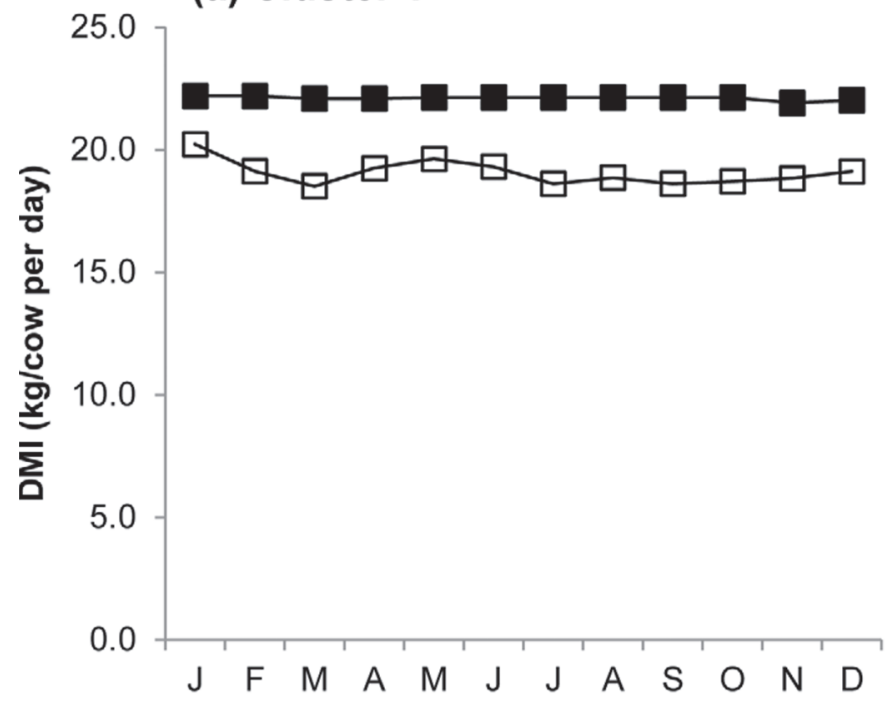

(b) Cluster 2

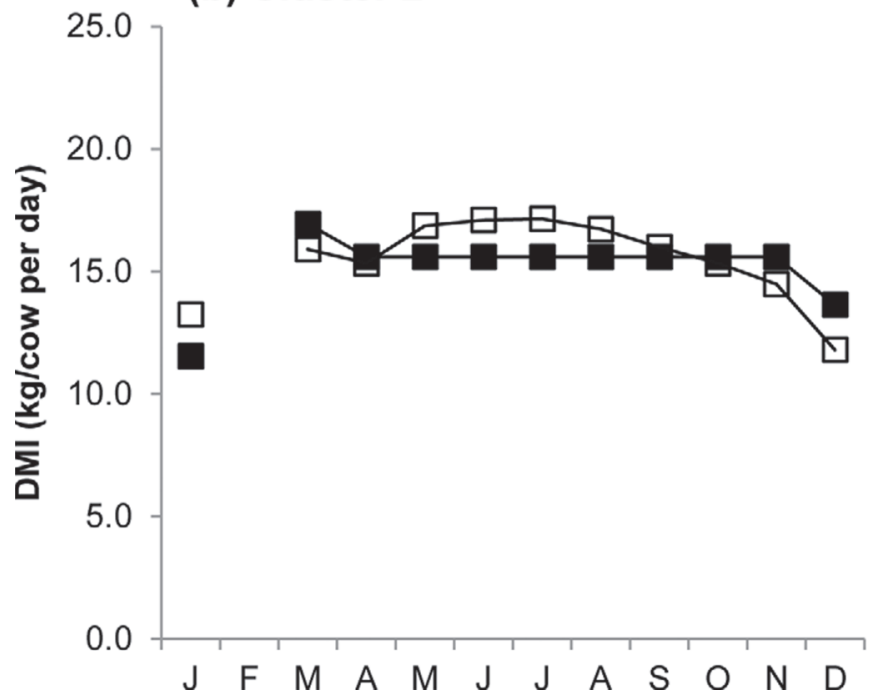

(c) Cluster 3

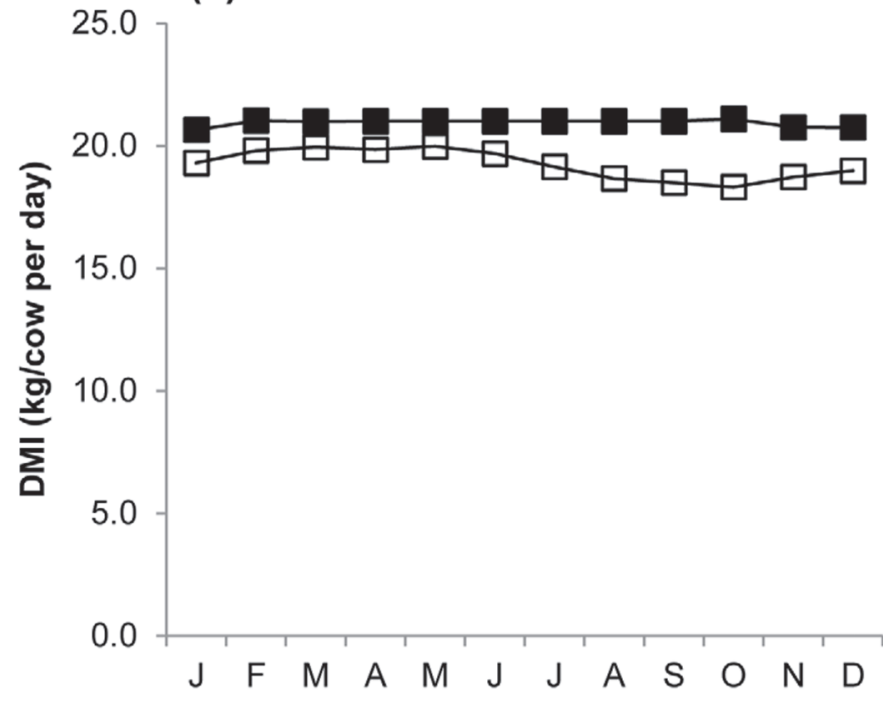

(d) Cluster 4

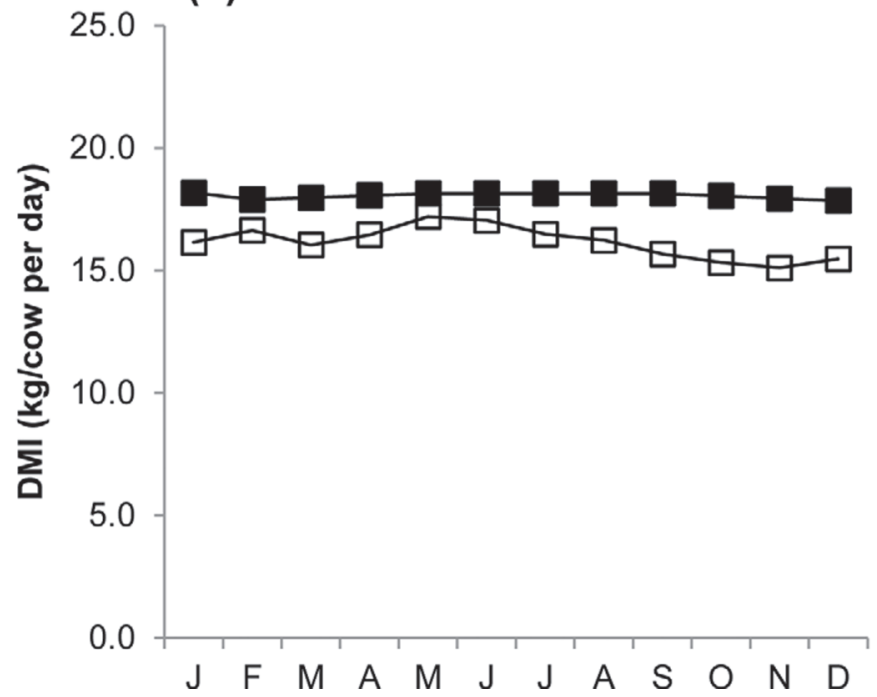

Figure 4. Comparison of 2 methods for calculating DMI for each cluster. In method 1 ( $\mathbf{\square})$, the total daily amount of feed supplemented during the nongrazing season was assumed to be the total daily DMI year round. Method $2(\square)$ approximated total DMI using a modified version of NRC $(2001)$ equation 1-2: $\left[\mathrm{DMI}=\left(0.372 \times \mathrm{FCM}+0.0968 \times \mathrm{BW}^{0.75}\right) \times\left(1-\mathrm{e}^{[-0.192 \times(\mathrm{WOL}+3.67)]}\right)\right]$, where WOL $=$ week of lactation. Note: in cluster 2, the missing values in February indicate that there were no lactating cows on any of that cluster's farms during that month. Average (SD) for method 1 DMI and method 2 DMI, respectively, by cluster: cluster 1: 22.1 (0.08) and 19.1 (0.49); cluster 2: 15.2 (1.42) and 15.5 (1.70); cluster 3: 20.9 (0.14) and 19.2 (0.60); cluster 4: 18.1 (0.11) and 16.2: (0.66).

farm costs such as unpaid labor, fuel, and machinery depreciation needs to be conducted before assessing profitability at the whole-farm level.

\section{ACKNOWLEDGMENTS}

This research was supported by Organic Agriculture Research and Extension Initiative Competitive Grant no. 2010-51300-20534 from the USDA National Institute of Food and Agriculture (Washington, DC).

\section{REFERENCES}

Auldist, M. J., M. F. S. Pyman, C. Grainger, and K. L. Macmillan. 2007. Comparative reproductive performance and early lactation productivity of Jersey $\times$ Holstein cows in predominantly Holstein herds in a pasture-based dairying system. J. Dairy Sci. 90:48564862 .

Bargo, F., L. D. Muller, J. E. Delahoy, and T. W. Cassidy. 2002. Performance of high producing dairy cows with three different feeding systems combining pasture and total mixed rations. J. Dairy Sci. 85:2948-2963.

Bargo, F., L. D. Muller, E. S. Kolver, and J. E. Delahoy. 2003. Invited review: Production and digestion of supplemented dairy cows on pasture. J. Dairy Sci. 86:1-42. 
Barrett, R., F. Miglior, G. Jansen, J. Jamrozik, and L. R. Schaeffer. 2005. Joint international evaluation of Milking Shorthorn dairy cattle for production traits. J. Dairy Sci. 88:3326-3336.

Caird, L., and W. Holmes. 1986. The prediction of voluntary intake of grazing dairy cows. J. Agric. Sci. 107:43-54.

Clark, D. A., and V. R. Kanneganti. 1998. Grazing management systems for dairy cattle. Page 311 in Grass for Dairy Cattle. J. H. Cherney and D. J. R. Cherney, ed. CAB International, Wallingford, UK.

Gehman, A. M., J. A. Bertrand, T. C. Jenkins, and B. W. Pinkerton. 2006. The effect of carbohydrate source on nitrogen capture in dairy cows on pasture. J. Dairy Sci. 89:2659-2667.

Hoshide, A. K., J. M. Halloran, R. J. Kersbergen, T. S. Griffin, S. L. DeFauw, B. J. LaGasse, and S. Jain. 2011. Effects of stored feed cropping systems and farm size on the profitability of Maine organic dairy farm simulations. J. Dairy Sci. 94:5710-5723.

Kolver, E. S., and L. D. Muller. 1998. Performance and nutrient intake of high producing Holstein cows consuming pasture or a total mixed ration. J. Dairy Sci. 81:1403-1411.

Leaver, J. D. 1985. Review article: Milk production from grazed temperate grassland. J. Dairy Res. 52:313-344.

Marston, S. P., G. W. Clark, G. W. Anderson, R. J. Kersbergen, M. Lunak, D. P. Marcinkowski, M. R. Murphy, C. G. Schwab, and P. S. Erickson. 2011. Maximizing profit on New England organic dairy farms: An economic comparison of 4 total mixed rations for organic Holsteins and Jerseys. J. Dairy Sci. 94:3184-3201.

Mayne, C. S., R. D. Newberry, and S. C. F. Woodcock. 1988. The effects of a flexible grazing management strategy and leader/follower grazing on the milk production of grazing dairy cows and on sward characteristics. Grass Forage Sci. 43:137-150.

McBride, W. D., and C. Greene. 2009. Characteristics, costs, and issues for organic dairy farming, ERR-82. USDA Economic Research Service, Washington, DC.

Mooi, E., and M. Sarstedt. 2011. A Concise Guide to Market Research. Springer-Verlag, Berlin, Germany.

NRC. 2001. Nutrient Requirements of Dairy Cattle. 7th rev. ed. Natl. Acad. Sci., Washington, DC.

Paine, L., and R. Gildersleeve. 2011. A Summary of Dairy Grazing Practices in Wisconsin. Wisconsin Department of Agriculture, Trade and Consumer Protection, Madison.

Pol, M., and P. L. Ruegg. 2007. Treatment practices and quantification of antimicrobial drug usage in conventional and organic dairy farms in Wisconsin. J. Dairy Sci. 90:249-261.

R Foundation for Statistical Computing. 2011. R Foundation for Statistical Computing, Vienna, Austria. Version 2.14.0. http:// www.r-project.org.

Rego, O. A., S. M. M. Regalo, H. J. D. Rosa, S. P. Alves, A. E. S. Borba, R. J. B. Bessa, A. R. J. Cabrita, and A. J. M. Fonseca. 2008. Effects of grass silage and soybean meal supplementation on milk production and milk fatty acid profiles of grazing dairy cows. J. Dairy Sci. 91:2736-2743.

Sato, K., P. C. Bartlett, R. J. Erskine, and J. B. Kaneene. 2005. A comparison of production and management between Wisconsin organic and conventional dairy herds. Livest. Prod. Sci. 93:105-115.
Smith, D. L., T. Smith, B. J. Rude, and S. H. Ward. 2013. Short communication: Comparison of the effects of heat stress on milk and component yields and somatic cell score in Holstein and Jersey cows. J. Dairy Sci. 96:3028-3033.

Stelwagen, K., C. V. C. Phyn, S. R. Davis, J. Guinard-Flament, D. Pomiès, J. R. Roche, and J. K. Kay. 2013. Invited review: Reduced milking frequency: Milk production and management implications. J. Dairy Sci. 96:3401-3413.

Stiglbauer, K. E., K. M. Cicconi, R. Richert, Y. H. Schukken, P. L. Ruegg, and M. Gamroth. 2013. Assessment of herd management on organic and conventional dairy farms in the United States. J. Dairy Sci. 96:1290-1300.

Undersander, D., B. Albert, D. Cosgrove, D. Johnson, and P. Peterson. 2002. Pastures for Profit: A Guide to Rotational Grazing. University of Wisconsin Cooperative Extension Publishing, Madison.

USDA-AMS (USDA Agricultural Marketing Service). 2010. National Organic Program: Access to Pasture (Livestock). 7 CFR Part 205. Accessed Mar. 12, 2013. http://www.ecfr.gov/cgi-bin/textidx?tpl=/ecfrbrowse/Title07/7cfr205_main_02.tpl.

USDA-AMS (USDA Agricultural Marketing Service). 2013. National Organic Program. Accessed Mar. 12, 2013. http://www.ams.usda. gov/AMSv1.0/nop.

USDA-ARS (USDA Agricultural Research Service). 2013. USDA Summary of 2012 Herd Averages DHI Report K-3. Accessed Mar. 20, 2013. http://aipl.arsusda.gov/publish/dhi/current/ha6.html.

USDA-ERS (USDA Economic Research Service). 2013. US Drought 2012: Farm and Food Impacts. Accessed Mar. 12, 2013. http:// www.ers.usda.gov/topics/in-the-news/us-drought-2012-farm-andfood-impacts.aspx.

USDA-NASS (USDA National Agricultural Statistics Service). 2012. 2011 Organic Production Survey: Wisconsin. Accessed Mar. 12 , 2013. http://www.nass.usda.gov/Statistics_by_State/Wisconsin/ Publications/WI_Organic_Release.pdf.

Vazquez, O. P., and T. R. Smith. 2000. Factors affecting pasture intake and total dry matter intake in grazing dairy cows. J. Dairy Sci. 83:2301-2309.

WDATCP (Wisconsin Department of Agriculture, Trade and Consumer Protection). 2010. Public Records. Accessed Nov. 5, 2010. http://datcp.wi.gov/contacts/Open_Records/.

Weigel, K. A., and R. Rekaya. 2000. A multiple-trait herd cluster model for international dairy sire evaluation. J. Dairy Sci. 83:815-821.

White, S. L., G. A. Benson, S. P. Washburn, and J. T. Green Jr. 2002. Milk production and economic measures in confinement or pasture system suing seasonally calved Holstein and Jersey cows. J. Dairy Sci. 85:95-104

Zwald, A. G., P. L. Ruegg, J. B. Kaneene, L. D. Warnick, S. J. Wells, C. Fossier, and L. W. Halbert. 2004. Management practices and reported antimicrobial usage on conventional and organic dairy farms. J. Dairy Sci. 87:191-201. 